\section{INDUSTRIAL ASSESSMENT OF BIOPATTERN IN THE APPLICATION OF CENTRIFUGAL BLOWER DESIGN AND HEAT INSULATION SYSTEM OF EXTRUDER}

\author{
Chin Toong Foo, Badrul Omar, Azlis Sani Jalil \\ Universiti Tun Hussein Onn Malaysia (UTHM), 86400 Parit Raja, Batu \\ Pahat Johor, Malaysia
}

Article history

Received

7 January 2020

Received in revised form

29 July 2020

Accepted

9 August 2020

Published online

27 August 2020

*Corresponding author

azlis@uthm.edu.my

\section{Graphical abstract}

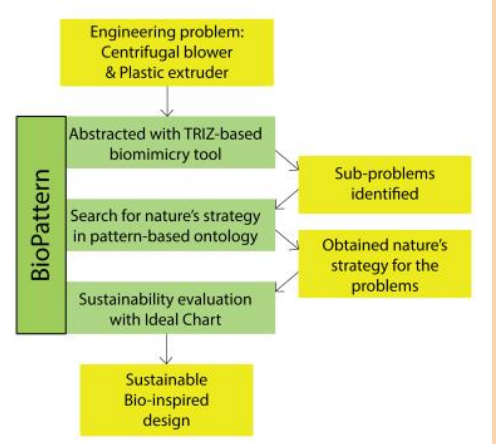

\begin{abstract}
BioPattern is a novel ideation tool for Bio-Inspired Design, built based on Theory of Inventive Problem Solving, SAPPhIRE Model of Causality, and pattern language. It has an ontology, known as pattern-based ontology, and a sustainability evaluation, known as Ideal Chart. However, this framework has not been tested yet to solve actual industrial problems. Therefore, this article is to present the results and analysis of the industrial case studies conducted to assess this biomimicry framework. Two different industries are selected. The industries presented a problem faced by each respective industry and the problems are to be solved by BioPattern. According to the constraints set by the industries, a suitable solution is found in the ontology while the concept generated is further evaluated by Ideal Chart. Based on the solutions produced from the case studies, BioPattern is found to be able to suggest technological solutions that are applicable in the industrial level with nature's strategies. It can be concluded that BioPattern is able to ease ideation by providing innovative ideas and sustainable inspiration from nature.
\end{abstract}

Keywords: TRIZ, SAPPhIRE, pattern language, centrifugal blower, heat insulation

\begin{abstract}
Abstrak
BioPattern merupakan alat ideasi yang baharu, dihasilkan daripada Teori Penyelesaian Masalah Inventif, Model sebab-akibat SAPPhIRE, dan corak-corak yang berulangan. Ia mempunyai sebuah ontologi, dikenali sebagai ontologi berasaskan corak-corak berulangan, dan sistem penilaian kemampanan, dikenali sebagai Carta Ideal. Manakala, rangka kerja ini belum diuji untuk menyelesaikan masalah yang dihadapi oleh pihak industri. Oleh itu, tujuan artikel ini adalah untuk membentangkan keputusan and analisis kajian kes industri ujian rangka kerja BioPattern. Dua buah industri yang berbeza telah dipilih. Pihak industri yang terpilih itu menampilkan sebuah masalah yang dihadapi oleh industri masing-masing yang perlu diselesaikan oleh BioPattern. Berdasarkan kekangan yang ditetapkan oleh pihak industri, cara penyelesaian yang sesuai didapati dari ontologi tersebut manakala Carta Ideal digunakan untuk menilai konsep yang terhasil itu secara lebih mendalam lagi. la didapati bahawa BioPattern boleh menghasilkan cara penyelesaian yang berprinsip alam semula jadi untuk teknologi pada peringkat industri. Kesimpulannya, BioPattern boleh memudahkan proses ideasi dengan menyediakan idea inovatif dan inspirasi yang lestari daripada alam semula jadi.

Kata kunci: TRIZ, SAPPhIRE, corak-corak berulangan, peniup empar, penebat haba

(C) 2020 Penerbit UTM Press. All rights reserved
\end{abstract}

\subsection{INTRODUCTION}

Nature has been on an ongoing research and development process in finding solutions to counter challenges be it with the principles of physics, mechanics, chemistry, material science, transportation, or sensors, from the range of nano to macro, a single cell to an entire ecosystem. It is a rich 
source of knowledge and inspiration of inventions as nature itself is an enormous collection of inventions that overcame the test of practicality and durability [1]. For example, before the first heat exchanger is being invented, the penguins, and tunas already had counter-current heat exchanger built in them to adapt in sub-zero environment [2]-[4]. Before Daniel Bernoulli introduces the Bernoulli's principle, nature had already been applying this principle for air ventilation in ant nests, termite mounds, and prairie dog's tunnels [5]-[7]. Bio-inspired design (BID) is the engineering design approach of designing functional products or processes by the inspiration of nature, which is biomimicry. The term "bio" means life and "mimicry" means an aptitude of copying. In other words, biomimetic is the development of innovative technologies, products, and processes based on the use of biological concepts. However, unless the gap between biology and engineering is bridged, the strategies from nature will not flow over into the engineering world. Even so, various strategies from nature had been successfully transferred with much effort yielding bio-inspired designs such as Velcroß [8], autonomous self-healing concrete [9], selfreinforced composites [10], oil repellent coating [11], acid resistance surface [12], water distribution and power grid networks [13], [14], and underwater adhesive [15].

Nature may be a source of inspiration and solution to the engineering world. However, engineers often struggle with the huge amount of biological information available from nature and not knowing which own to use [16]. This is often because the terminologies in biology is not common to engineers. This had made the adaptation process in BID difficult as they do not know how to extract or where to find these inspirations from. Ontology-based search method is claimed to be the best way to bridge the biology-engineering gap [17]. But existing ontologies are not robust enough; either it is incomplete [18], abstracted models of poor quality [19], or having a small database [19], [20]. Foo presented that there are three potential approaches to bridge the biology-engineering gap [21]; which are TRIZ (Teoriya Resheniya Izobretatelskikh Zadach) translated as the Theory of Inventive Problem Solving [22]-[24], SAPPhIRE model of causality [25], [26], and pattern language [27].

Based on the research gap discovered by Foo, a biomimicry design approach was developed, called BioPattern. Biomimicry models are often related to innovation of inventions, or generating concepts for new inventions. This paper aims to assess the practicality of this newly developed biomimicry design framework with engineering problems faced by the industry with machineries. Two different problems are presented by two different appointed industries, Industry A and Industry B. Industry A is a machine manufacturing company where they manufactured different types of machinery, such as plastic crusher, centrifugal blower, cyclone machine, and also sludge filtering machine, while Industry B is a small and medium enterprise plastic injection moulding company.

The following sections describes the methodology of the case studies, and the outcome of the concepts generated.

\subsection{METHODOLOGY}

\subsection{BioPattern}

BioPattern is a TRIZ-based and pattern-based design framework with a Function-Behaviour-Structure (FBS) abstraction tool to abstract biological information. TRIZ is known to be the most promising tool that could facilitate the bridge the gap between biology and engineering [17], [28]-[30]. This is because TRIZ is able to zoom out from a problem, search for a solution from a different discipline, and zoom back into the problem with the newly found solution. Figure 1 shows the TRIZ cycle of how a technical problem is transferred into a biological problem by BioPattern, and search for a biological solution that solves the problem. Then the biological solution is transferred as a new technical solution. The TRIZ cycle is further broken down into a double TRIZ cycle, where the first TRIZ cycle addresses the breaking down of problem to sub-problems, transferring it to a general biological context and then search for a specific biological problem. The second TRIZ cycle addresses the abstraction of the biological solution and transferring the biological solution to a general technical solution, and finally applied to the target as a new specific technical solution.

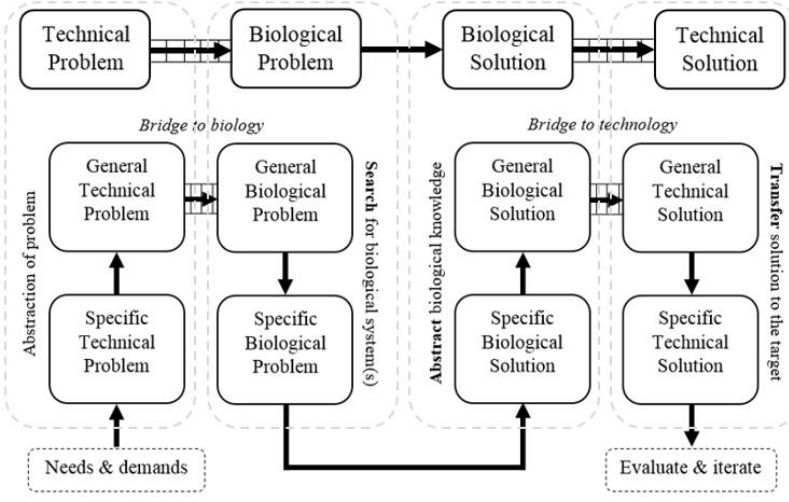

Figure 1 Problem-driven BioPattern design process

BioPattern has a database of over 200 biological systems abstracted and compiled into a nature's pattern-based ontology. The ontology addresses a total of 86 problems grouped within 19 categories with 254 strategies from nature. By obtaining the subproblems revealed in the problem definition stage, the keyword of the sub-problem is searched through the pattern-based ontology for a solution by nature that addresses the problem. The nature's solution as 
the conceptual design is evaluated by the sustainability evaluation tool.

The sustainability evaluation tool, which is Ideal Chart, is an integrated model of 9-Windows and the Law of Ideality. With Ideal Chart, the concept generated can be further developed until it is more sustainable and ready to be developed in the next stage (embodiment design). The concept is evaluated based on cost and material source with a list of criteria from the Law of Ideality classified based on their level of influence. These criteria evaluates how the system can be improved to be more selfsustaining; how does the system react with the supersystem, and how the sub-system can be even more efficient.

\subsection{Case Study 1: Centrifugal Blower}

A centrifugal blower is a mechanical device where suction of air is drawn into the middle of the blower housing by a set of rotating impeller blades with radial force and channelling the fluid flow out radially. The problem given by Industry $A$ is to increase the suction power of a centrifugal blower with a carbon steel impeller without increasing power consumption. A constrain is given where the impeller design is not allowed to be modified. The only manipulating variable is the material of the impeller and the number of blades. Figure 2 shows the sample of centrifugal blower designed by Industry A.

By breaking down the problem using the problem definition stage of BioPattern, one of the contributing factors that greatly affects the main objective is the weight of the impeller as it is discussed in step 2(b) Table 1. The objective is now shifted from energy saving to lightweight structures. A nature's solution in the pattern-based ontology is found based on the keyword "lightweight structure". The suggested strategy is presented in section 3.1. The solution is then further evaluated with Ideal Chart. The outcome of the evaluation is also presented in section 3.1. Material selection charts by Michael Ashby [31] are then used as reference to determine the most efficient material to be used as an alternative material.

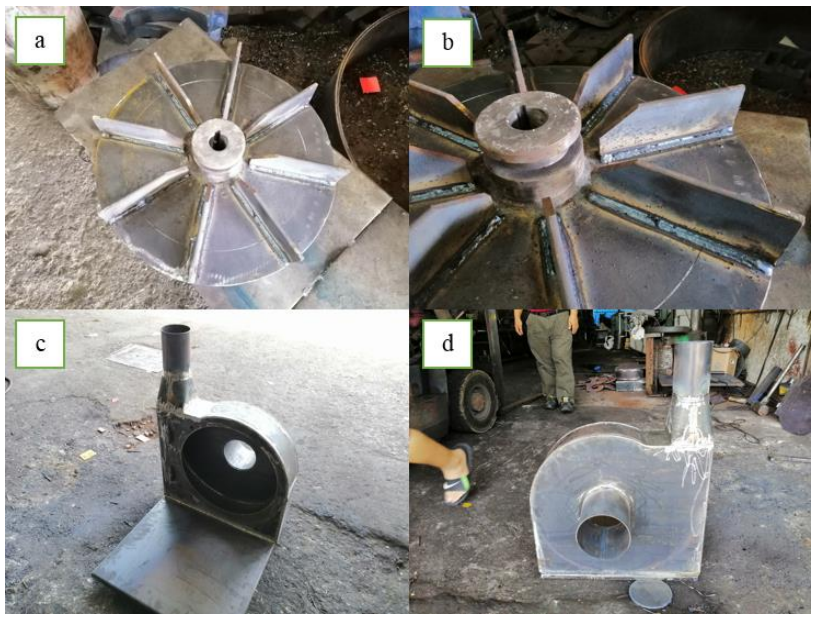

Figure 2 Sample product from Industry A (a, b) blower impeller and $(c, d)$ housing

Note that the power of the motor is not specified by the industry, thus, no formula can be derived and the material selection charts are only used as references to obtain the optimized material as alternative.

Table 1 Problem definition of blower impeller

\begin{tabular}{|l|l|l|}
\hline Step & Description & Result solution \\
\hline 1 & $\begin{array}{l}\text { Determine the final goal of a solution. } \\
\text { a) What is the technical goal? } \\
\text { b) What is the constant variable? } \\
\text { c) What is the manipulated variable? } \\
\text { d) What is the Ideal Final Result (IFR)? }\end{array}$ & $\begin{array}{l}\text { a) To increase the suction power without } \\
\text { increasing power usage. } \\
\text { b) Impeller design. } \\
\text { c) Material and number of blades. } \\
\text { d) Suction power increased with no power } \\
\text { needed. }\end{array}$ \\
\hline 2 & $\begin{array}{l}\text { Breaking down the problem into sub-problems to identify the } \\
\text { actual problem to be solved. } \\
\text { a) What is the super-system (surrounding) to the system? } \\
\text { b) What should be added into / removed from the system? }\end{array}$ & $\begin{array}{l}\text { a) Air. } \\
\text { b) Weight of the impeller should be reduced. }\end{array}$ \\
\hline
\end{tabular}

\subsection{Case Study 2: Plastic Extruder}

On the other hand, Industry B is regularly faced with the issue of blocked plastic material at the feed section. Figure 3 shows a cross-section layout of an extrusion barrel. The plastic resin is fed into the feed section (feed zone) via the throat of the hopper and melted in the compression section, also known as the melting zone. The diameter of the screw in the barrel increases in the latter sections of the barrel. This is to raise the pressure within the barrel as more melts are pushed to the metering section (melt-pumping zone). Blockage in the extruder happens because the heat conducted from heater bands and cartridge heater in compression and metering section flowed into the feed section, causing the plastic resin to melt prematurely. Such phenomena only happens when materials are loaded into the feed section but not carried away into the compression section immediately. A solution to prevent premature melting 
of plastic resin in the feed section is required to prevent blockage in the extruder.

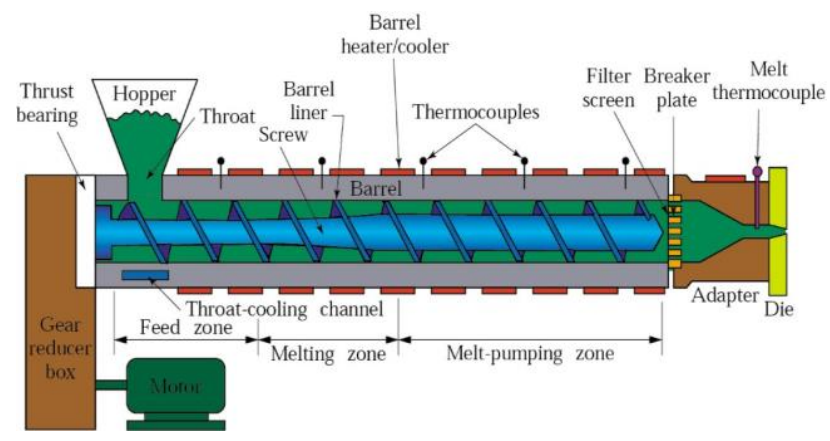

Figure 3 Extrusion barrel layout [32]

The objective of this case study is to prevent plastic melting prematurely within the feed section. Therefore, a solution is needed to prevent plastic melts clogging the feed section. With the problem definition in Table 2, heat insulation is the main issue that required a solution. Therefore, strategies of the category "thermoregulation" is referred from the ontology.

Based on the keyword "thermoregulation", nature's strategies are obtained from the patternbased ontology, and the concept is evaluated with Ideal Windows. The outcome of the solution suggested is presented in section 3.2.

In order to test the strategy suggested by BioPattern, a comparison heat conduction thermal study is simulated for both models of non-insulated and ceramic-insulated thermal study with SolidWorks 2016. The model of non-insulated study is made up of a bi-layer model, as shown in Figure 4(a); a highdensity polyethylene (HDPE) cylinder (diameter: 280 $\mathrm{mm}$, length: $400 \mathrm{~mm}$ ) and a hollow grey cast iron cylinder (Internal diameter: $280 \mathrm{~mm}$, thickness: 60 $\mathrm{mm}$, length: $400 \mathrm{~mm}$ ). As for the model of ceramicinsulated thermal study is made up of a tri-layer model, as shown in Figure 4(b); a HDPE cylinder (diameter: $280 \mathrm{~mm}$, length: $400 \mathrm{~mm}$ ), a hollow porcelain cylinder (Internal diameter: $280 \mathrm{~mm}$, thickness: $30 \mathrm{~mm}$, length: $400 \mathrm{~mm}$ ), and a hollow grey cast iron cylinder (Internal diameter: $340 \mathrm{~mm}$, thickness: $30 \mathrm{~mm}$, length: $400 \mathrm{~mm}$ ).

An external heat source of $2000 \mathrm{~W}$ is supplied directly onto the outermost surface to simulate the heater bands, the initial temperature of the model is $25^{\circ} \mathrm{C}$, and the temperature of the outermost surface of cast iron is set at $200{ }^{\circ} \mathrm{C}$ as preheating is a common practice in extrusion machine. The solution type of the thermal study is set as transient as the result is dependent to time. A total time of 1800 seconds, which is 30 minutes, with 10 time steps of 100 seconds per increment. The solver used is FFEPlus, which is the default solver.

An external heat source of $2000 \mathrm{~W}$ is supplied directly onto the outermost surface to simulate the heater bands, the initial temperature of the model is $25^{\circ} \mathrm{C}$, and the temperature of the outermost surface of cast iron is set at $200{ }^{\circ} \mathrm{C}$ as preheating is a common practice in extrusion machine. The solution type of the thermal study is set as transient as the result is dependent to time. A total time of 1800 seconds, which is 30 minutes, with 10 time steps of 100 seconds per increment. The solver used is FFEPlus, which is the default solver.

The result of the simulation is also presented in section 3.2 .

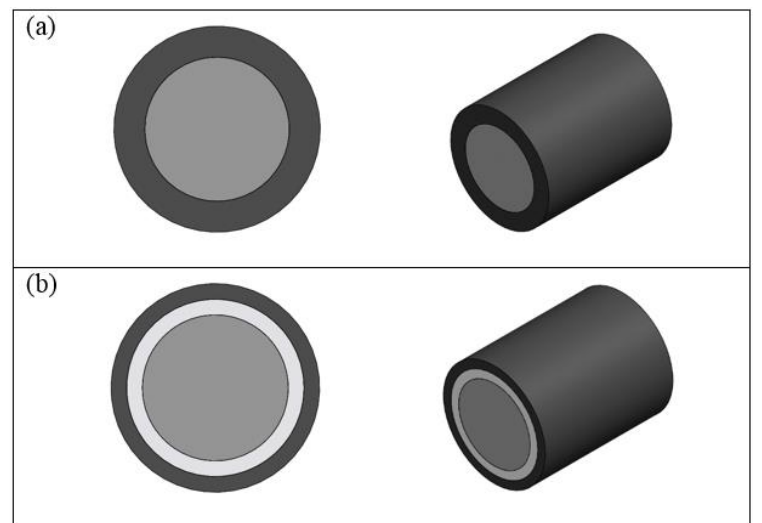

Figure 4 (a) Non-insulated thermal study modelling. (Black grey cast iron, grey - HDPE), and (b) insulated heat study modelling. (Black - grey cast iron, white - ceramic porcelain, grey - HDPE)

Table 2 Problem definition of extruder insulation

\begin{tabular}{|c|l|l|}
\hline Step & Description & Result solution \\
\hline 1 & $\begin{array}{l}\text { Determine the final goal of a solution. } \\
\text { a) What is the technical goal? } \\
\text { b) What is the constant variable? } \\
\text { c) What is the manipulated variable? } \\
\text { d) What is the Ideal Final Result (IFR)? }\end{array}$ & $\begin{array}{l}\text { a) To prevent plastic melt prematurely in the feed } \\
\text { section. } \\
\text { b) Dimension of the feed section. } \\
\text { c) Heat insulation methods. } \\
\text { d) No heat flow into the feed section. }\end{array}$ \\
\hline 2 & $\begin{array}{l}\text { Breaking down the problem into sub-problems to identify the actual } \\
\text { a) What is the super-system (surrounding) to the system? } \\
\text { a) What should be added into / removed from the system? }\end{array}$ & $\begin{array}{l}\text { a) Plastic / HDPE resins. } \\
\text { b) Add heat insulator. }\end{array}$ \\
\hline
\end{tabular}


Table 3 Strategy description of "layered composite" from pattern-based ontology

\begin{tabular}{|ll|l|l|l|c|}
\multicolumn{1}{|c|}{ Category } & \multicolumn{1}{c|}{ Problem } & \multicolumn{1}{c|}{ Strategy } \\
$\begin{array}{l}\text { Material } \\
\text { (reduction) }\end{array}$ & cost & $\begin{array}{l}\text { Lightweight } \\
\text { structures }\end{array}$ & $\begin{array}{l}\text { Layered } \\
\text { composite }\end{array}$ & $\begin{array}{l}\text { Increased impact time } \\
\text { dissipates impact. }\end{array}$ & $\begin{array}{l}\text { Scaly-foot snail, } \\
\text { Cassowary, Venus's Flower Basket }\end{array}$ \\
\hline
\end{tabular}

\subsection{RESULTS AND DISCUSSION}

Section 3.1 presents the outcome suggested by BioPattern for Case Study 1 while section 3.2 for Case Study 2. The material selection chart and thermal study are both verification for the suggested solution by BioPattern for both case studies, respectively.

\subsection{Case Study 1: Lightweight Impeller Blades}

Based on the keyword "lightweight structure" abstracted from the specific problem, the strategy suggested by the pattern-based ontology is "layered composite" (Table 3), inspired by scally-foot snail, as shown in Figure 5. A layered composite is a structure that is formed by bonding weak and strong materials together so that the new material could have the best of both materials. A weak base material will be used for the impeller while a stronger reinforcement material will be used to sandwich the weak material for the blade. Scally-foot snail shell is a three-layer structure composite, consists of an outer layer embedded with iron sulphide, a thick organic middle layer, and a calcified inner layer, that resist penetration, mitigate fracture and crack arrest, dissipates mechanical energy, reduce back deflections, and resist bending and tensile loads [33]. The scally-foot snail shell is an example of natural occurring sandwich panel. With this strategy offered by the ontology, the concept generated is to replace the impeller with sandwich panel to reduce the weight while maintaining the strength of the impeller. This concept is then evaluated with Ideal Windows, as shown in Table 4.

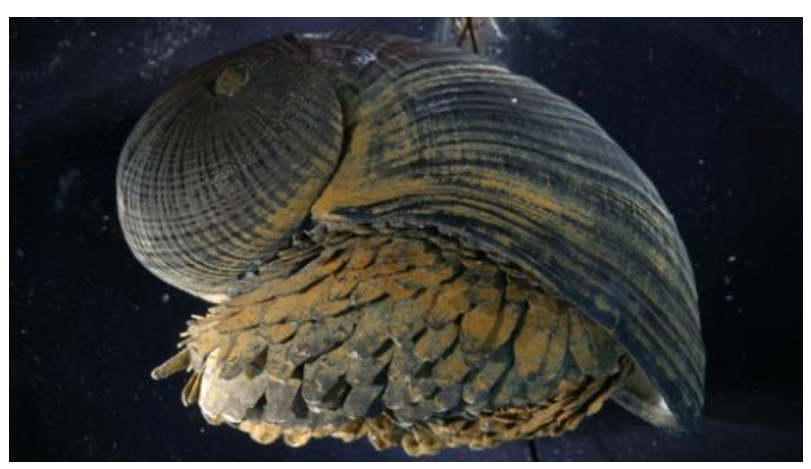

Figure 5 Scally-foot snail, Crysomallon squamiferum [34]

Since the maximum allowable stress acting on the impeller and original suction velocity are unknown, searching for an alternate material with a specific yield strength or modulus is impossible. Therefore, a range of material is chosen based on assumptions and comparing the alternate material from the original material. The original material is carbon steel plates welded together. In order to select a cheaper, stronger and lighter material, material selection charts by Michael Ashby [31] are employed.

Note that no formula is used because there are no specifications on the dimensions, suction power, and energy requirement given by Industry A. Therefore, this is a conceptual problem solving and the material selection charts are only used as references.

Table 4 Ideal Windows for blower impeller

\begin{tabular}{|c|c|c|c|}
\hline & Ideality Principles & $\begin{array}{l}\text { Interaction between } \\
\text { spaces }\end{array}$ & Ideality technique \\
\hline 㝘皆 & $\begin{array}{l}\text { Transfer some functions to a super-system. } \\
\text { - Reduction of disturbances caused by } \\
\text { structures. } \\
\text { - Decrease the area of harmful effects. }\end{array}$ & $\begin{array}{l}\text { What happens to } \\
\text { the } \\
\text { super-system? }\end{array}$ & $\begin{array}{ll}\text { - } & \text { N/A } \\
& \text { Reduce the weight of the impeller. } \\
& \text { N/A }\end{array}$ \\
\hline$\frac{\varepsilon}{\frac{\varepsilon}{\omega}}$ & $\begin{array}{l}\text { - Multifunctional design. } \\
\text { - Improve the performance of some functions. } \\
\text { chemical, geometrical and other effects and } \\
\text { gradients as energy resources. }\end{array}$ & System in use. & $\begin{array}{ll}\text { - } & \text { N/A } \\
\text { - Increasing the strength of the impeller } \\
\text { - } \quad \text { with reinforced material. } \\
\text { Reduce the weight of the impeller. }\end{array}$ \\
\hline 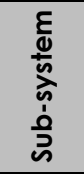 & $\begin{array}{l}\text { - Save material cost by using existing material } \\
\text { resources. } \\
\text { - Unifying/Removing redundant parts. } \\
\text { - Provide easier access and prevent waste of } \\
\text { energy. }\end{array}$ & $\begin{array}{l}\text { What happens } \\
\text { within } \\
\text { the system? }\end{array}$ & $\begin{array}{l}\text { - Using polymer as the main material } \\
\text { reinforced with thin metal plates. } \\
\text { - N/A } \\
\text { - N/A }\end{array}$ \\
\hline
\end{tabular}




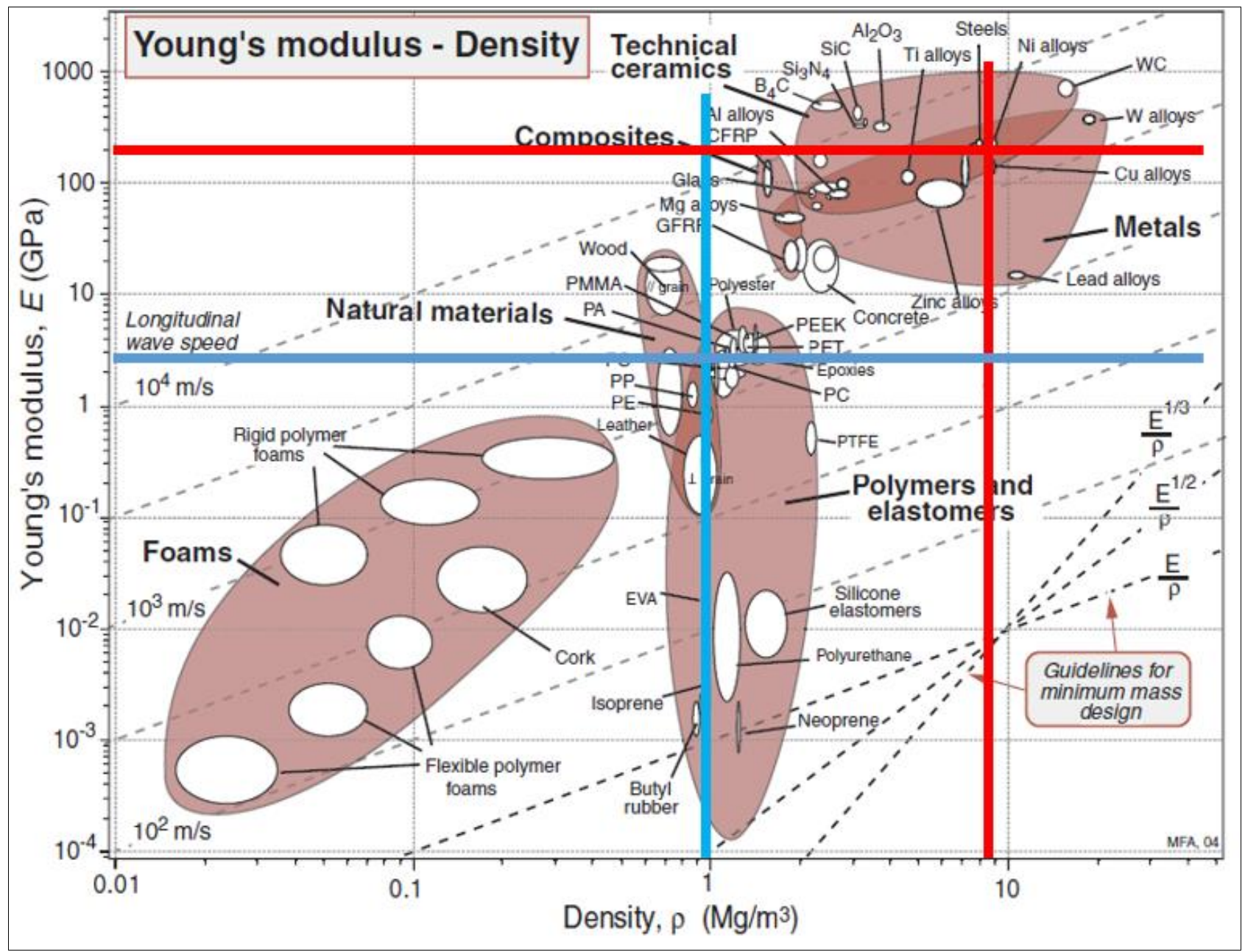

Figure 6 Young's modulus versus density material chart [31]. Red lines intersect at the region of steel, blue lines intersect at the region of polymer

The selected material that is used as the alternative for carbon steel should be a material of Young's modulus that is as close as possible to that of the original material (Young's modulus $\approx 200 \mathrm{GPa}$ ) and needed to be as light as possible (Density $<8.5$ $\left.\mathrm{Mg} / \mathrm{m}^{3}\right)$. According to Young's modulus-Density material selection chart in Figure 6, materials that have density lower than $8.5 \mathrm{Mg} / \mathrm{m}^{3}$ are foams, natural materials, polymers, and composites. Materials that have the most similar Young's modulus are composites, followed by natural materials and polymer. Natural materials are eliminated because natural materials decay over time, while foams have Young's modulus that are too low to be used as impeller blades. The range of materials to be chosen from Figure 5 converged to polymers and composites. Polymers such as polyethylene (PE), polypropylene (PP), or polyethylene terephthalate (PET) are strong polymers compared to isoprene, neoprene, rubber, or polyurethane which only have the Young's modulus of foams. Another material that is light and strong is carbon fibre reinforced polymer (CFRP) from the groups of composites.

The preliminary screening had filtered the materials until there are only PP, PE, PET, and CFRP left. Referring to the Modulus-Relative cost/volume chart shown in Figure 7, it shows that the price of CFRP is the highest $\left(C_{V, R}\right.$ (CFRP) $\approx 11.3$ ) and is 10 times more expensive than using the carbon steel $\left(C_{V, R}\right.$ (carbon steel) $\approx 1.0$ ). Therefore, CFRP is eliminated, leaving the alternatives with only PP, PE, and PET with a relative cost per unit volume of approximately 0.28 . The mechanical characteristics of all this three materials are very similar, therefore, all this three materials are suggested as the replacement material of the impeller. As for the reinforcement material, 1 $\mathrm{mm}$ carbon steel plate is attached onto the leading surface of the impeller blades, or both the surfaces of the impeller blades. 


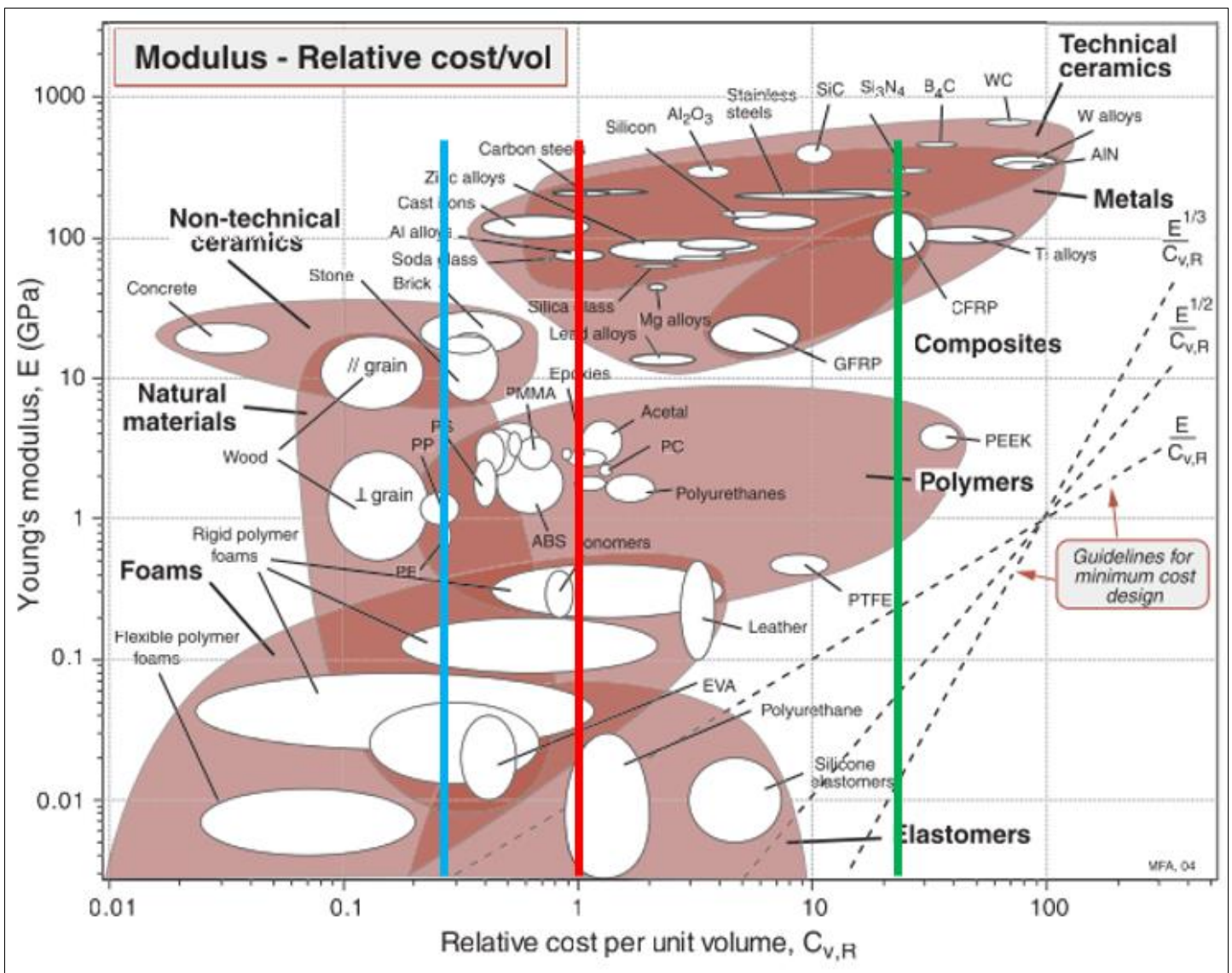

Figure 7 Young's modulus versus relative cost per unit volume material chart [31]. Red line intersects at the region of carbon steel. Blve line intersects at the region of PP and PE. Green line intersects at the region of CFRP

Therefore, the suggested solutions to the problem is as follows:

1. Reduce mass of material. The material suggested based on material selection chart is plastic/polymer. High dense polyethylene (HDPE) or polyethylene terephthalate (PET).

2. Tri-layer composite is used to make the propellers stronger by sandwiching polymer with thin layer of metal sheet.

3. Increasing the number of propellers in the blower.

Since the material had been replaced with a lighter material, the power required to rotate the impeller is reduced. Furthermore, increasing the number of blades of the impeller also increases the suction velocity.

\subsection{Case Study 2: Extruder Insulation}

Table 5 shows the strategies suggested by patternbased ontology with the query keyword "thermoregulation" abstracted from the problem. The strategies suggested are "high specific heat capacity", "cooling ribs", and "increase exposure". The strategy of "high specific heat capacity" is inspired by how malleefowl incubates eggs on mound of rotting vegetation as heat is generated from the compost to warm the eggs, as shown in Figure 8. The mound is covered with a layer of sand to insulate heat from the surrounding, at the same time allows excessive heat to flow out. Another function of sand is to insulate the heat from the sun from overheating the eggs as sand have high specific heat capacity [35].

Table 5 Strategy description of "high specific heat capacity", "cooling ribs", and "increase exposure" from pattern-based ontology

\begin{tabular}{|l|l|l|l|l|}
\hline Category & Problem & Strategy & \multicolumn{2}{l|}{ Description } \\
\hline Thermoregulation & $\begin{array}{l}\text { Heat } \\
\text { insulation }\end{array}$ & $\begin{array}{l}\text { High specific } \\
\text { heat capacity }\end{array}$ & $\begin{array}{l}\text { The material is heated up slowly } \\
\text { but loses heat quickly. }\end{array}$ & Malle fowl \\
\hline Thermoregulation & Keep cool & Cooling ribs & $\begin{array}{l}\text { Heat dissipates with increased } \\
\text { surface area. }\end{array}$ & $\begin{array}{l}\text { Cactus, African Bush Elephant, } \\
\text { Black-tailed Jackrabbit }\end{array}$ \\
\hline Thermoregulation & Keep cool & $\begin{array}{l}\text { Increase } \\
\text { exposure }\end{array}$ & Exposes heat to wide surface. & $\begin{array}{l}\text { African Bush Elephant, Birds, } \\
\text { Cactus, Black-tailed Jackrabbit }\end{array}$ \\
\hline
\end{tabular}




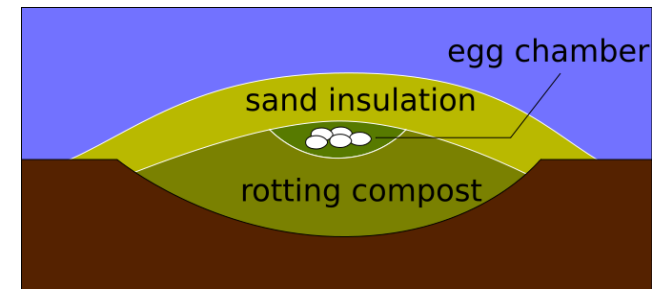

Figure 8 Malleefowl incubating mound [36]

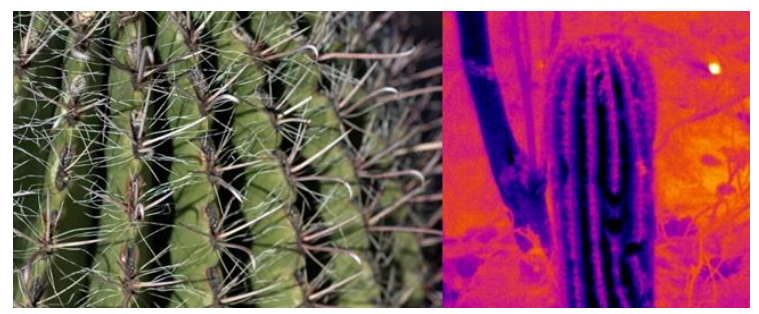

Figure 9 Ridges on barrel cactus (left) [37] and infrared image of barrel cactus (right) [38]
The strategy of "cooling ribs" is inspired by barrel cactus. As shown in Figure 9, the ridges shades a huge part of the cactus body from being exposed to sunlight which directly reduces the overall temperature of the cactus [39], [40]. Furthermore, the ridges also increases the total surface area, which also leads the strategy "increase exposure" where heat loss is greater over a larger surface area. However, the most relevant solution for this case is by increasing the total surface area as the heat source is via conduction and not radiation.

The strategies are then evaluated with Ideal Windows, as shown in Table 6. Noticed that as stated in the seventh criteria of the Ideal Window evaluation, a high specific heat capacity material is required to insulate the heat transferring from the compression and metering section. In general, ceramics have higher specific heat capacity compared to that of cast iron. Therefore, more energy is required to raise the temperature of $1 \mathrm{~kg}$ of ceramic by 1 Kelvin.

Table 6 Ideal Windows for extruder insulation

\begin{tabular}{|c|c|c|c|}
\hline & Ideality Principles & $\begin{array}{l}\text { Interaction between } \\
\text { spaces }\end{array}$ & Ideality technique \\
\hline 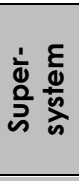 & $\begin{array}{l}\text { - Transfer some functions to a super-system. } \\
\text { - Reduction of disturbances caused by } \\
\text { structures. } \\
\text { - } \text { Decrease the area of harmful effects. }\end{array}$ & $\begin{array}{l}\text { What happens to } \\
\text { the } \\
\text { super-system? }\end{array}$ & $\begin{array}{l}\text { - Increase surface exposed to water } \\
\text { cooling system. } \\
\text { - N/A } \\
\text { - The insulator must be bonded to the } \\
\text { barrel. }\end{array}$ \\
\hline$\frac{\varepsilon}{\frac{\varepsilon}{\omega}}$ & $\begin{array}{l}\text { - Multifunctional design. } \\
\text { - } \quad \text { Improve the performance of some functions. } \\
\text { cheme energy cost by utilizing physical, } \\
\text { gradients as energy resources. }\end{array}$ & System in use. & $\begin{array}{l}\text { - } \quad \text { N/A } \\
\text { - Adding cooling fins within the water } \\
\text { capillaries. } \\
\text { Increase surface exposed to water } \\
\text { cooling system. }\end{array}$ \\
\hline 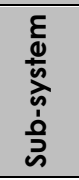 & $\begin{array}{l}\text { - Save material cost by using existing material } \\
\text { resources. } \\
\text { - Unifying/Removing redundant parts. } \\
\text { - Provide easier access and prevent waste of } \\
\text { energy. }\end{array}$ & $\begin{array}{l}\text { What happens } \\
\text { within } \\
\text { the system? }\end{array}$ & $\begin{array}{l}\text { - High specific heat capacity material } \\
\text { as insulator. } \\
\text { - Use high temperature resistance } \\
\text { silicone as bonding material. } \\
\text { - N/A }\end{array}$ \\
\hline
\end{tabular}

The results of the simulation, in the form of heat contour, is shown in Figure 10 and Figure 11 for noninsulated and ceramic-insulated model, respectively. In just the third time step (300 s) of the non-insulated study, the outermost region of the HDPE had become orange in colour, where the temperature is raised to approximately $170{ }^{\circ} \mathrm{C}$. The HDPE layer had already melted at this temperature as the melting point of HDPE is between $110 \sim 130^{\circ} \mathrm{C}$. The melting process begins at the second time step. At the fourth time step (400 s), the outermost region of HDPE almost reached $200^{\circ} \mathrm{C}$. Finally, the outermost region of HDPE reached $200{ }^{\circ} \mathrm{C}$ starting from the seventh time step (700 s).

The results of ceramic-insulated study is, however, much better compared to the result of non-insulated study. At the second time step (200 s), the porcelain insulation outermost layer almost reached the temperature of $200{ }^{\circ} \mathrm{C}$, while maintaining the innermost layer at $25^{\circ} \mathrm{C}$. At the fourth time step (400 s), the temperature of the outermost layer of HDPE begin to raise until approximately $60^{\circ} \mathrm{C}$. Only at the seventh time step $(700 \mathrm{~s})$, the temperature of the outermost layer of HDPE had reached the melting point. At the eighteenth time step (1800 s), which is also the final time step, the outermost layer of HDPE is barely yellow in colour while the porcelain is almost fully red. This shows that ceramic has very good heat resistivity.

Finally, the practicality of ceramic as the selected insulation material should be the final consideration. Ceramics are robust and does not break easily. Ceramics can withstand high tensile and also pressure exerted by asperity contacts. Therefore, the suggested solutions to the problem is as follows:

1. Insulating feeder section with material of high specific heat capacity and high melting point. The material suggested based on material selection chart is ceramic. Ceramic 
is chosen because it is durable and have a higher heat expansion tolerance.

2. Increasing surface area exposed to cooling fluid. (a) By adding cooling fins within the cooling fluid capillaries. (b) By increasing the length of the capillary system.

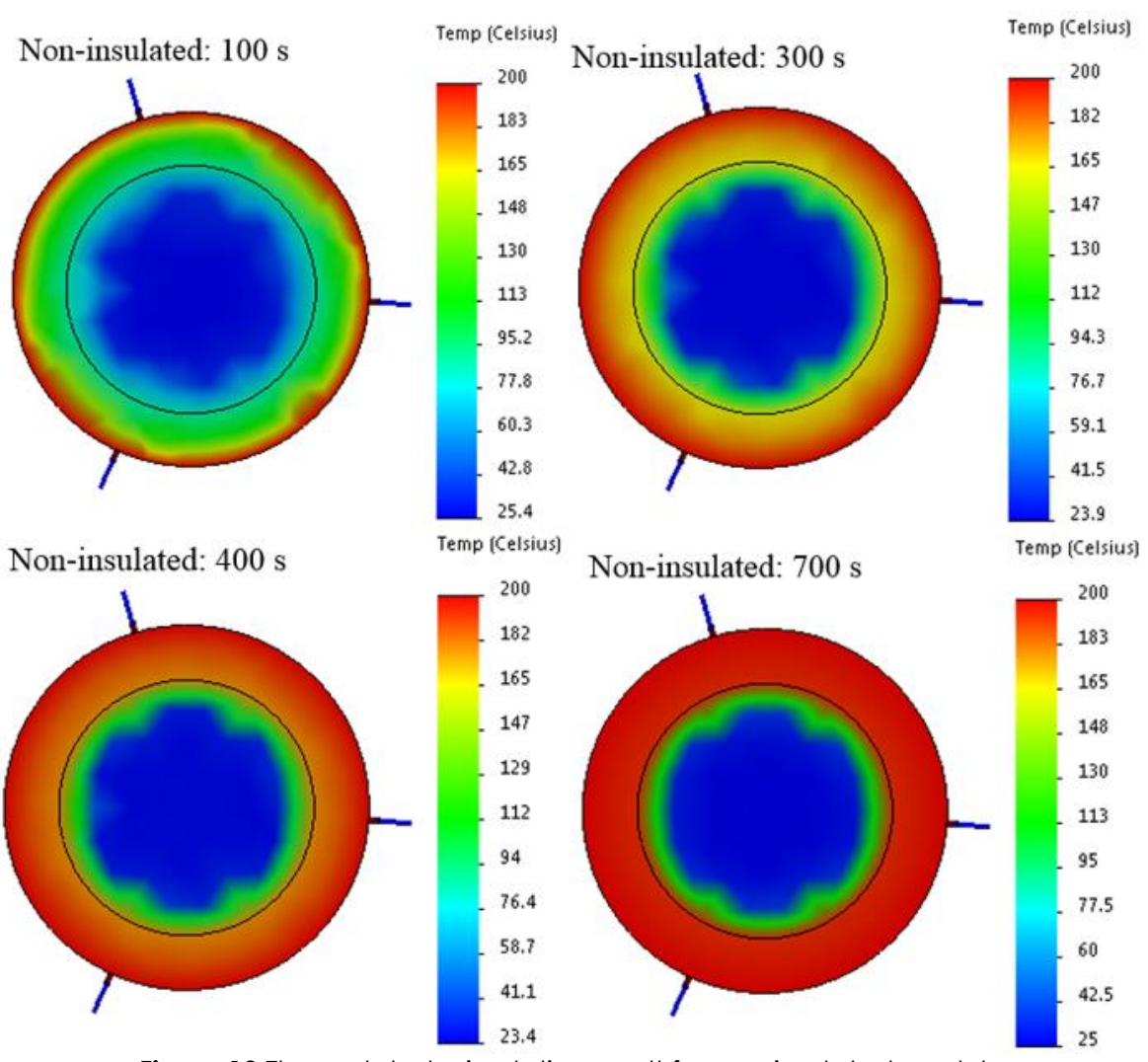

Figure 10 Thermal study simulation result for non-insulated model
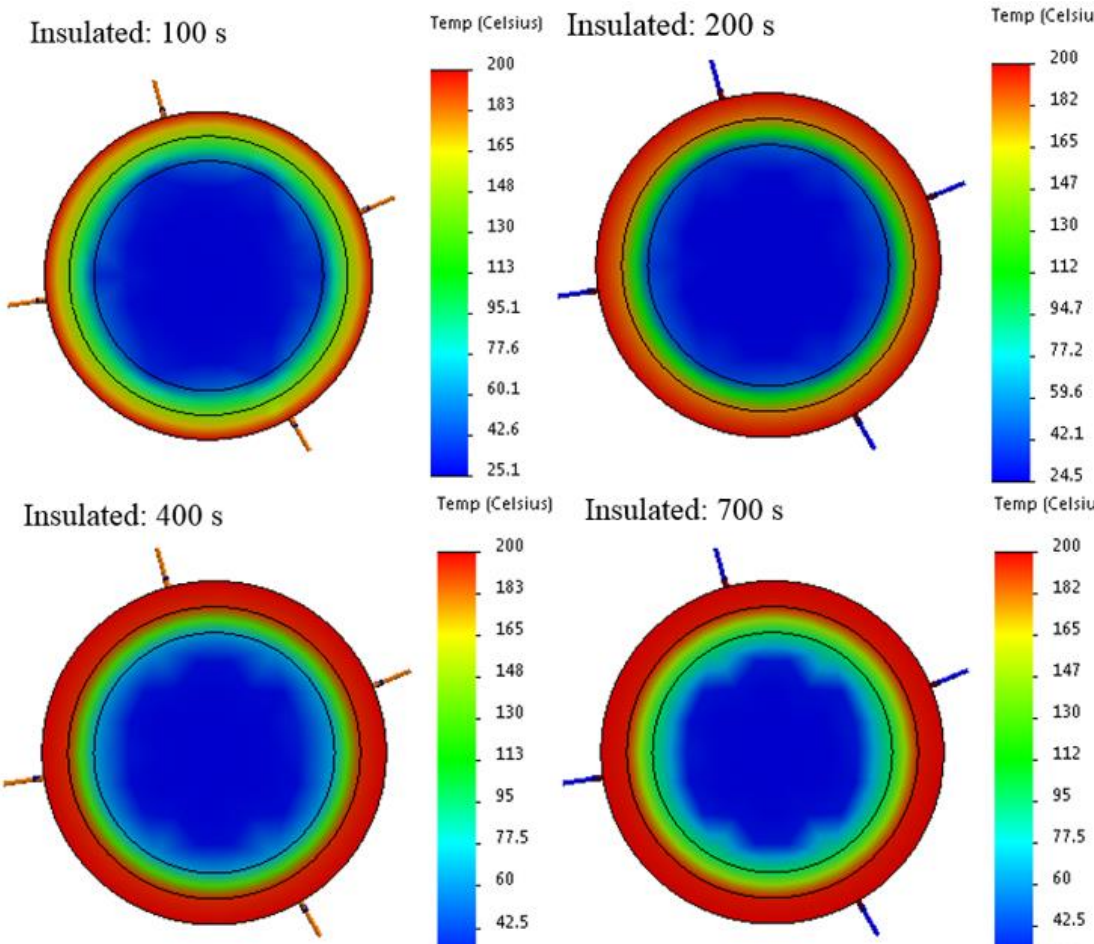

Temp (Celsius) Insulated: $700 \mathrm{~s}$
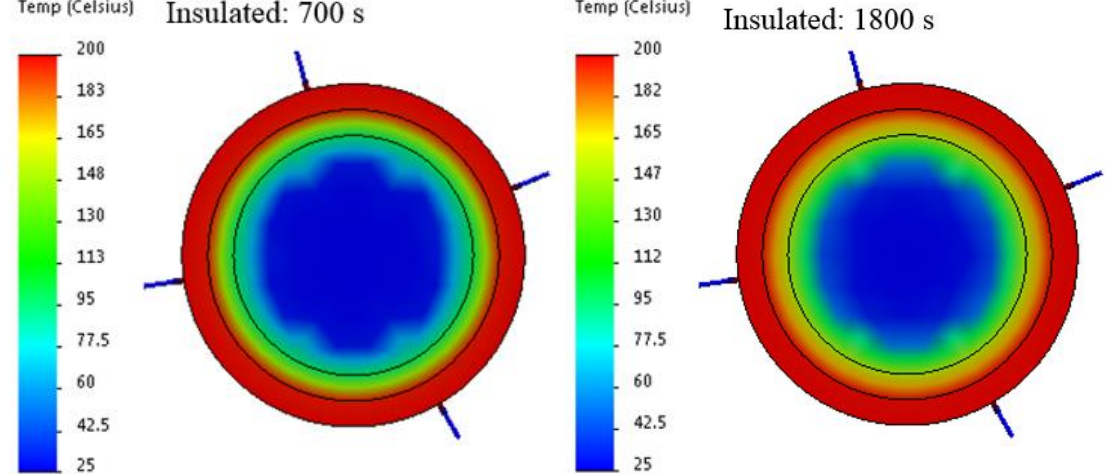

Temp (Celsius)

Figure 11 Thermal study simulation result for insulated model 


\subsection{Practicality of BioPattern}

Since both case studies are problem-driven approach, therefore the first step for both case studies is problem definition. The problem definition stage is very important because the realization of the concept is to address the problem. If the problem is vague at the first place, the solution will not be able to solve the actual problem that is needed to be addressed. BioPattern have a clear problem definition stage where the given problem is broken down structurally and the variables and constraints are identified. The second step of BioPattern analyses the problem in terms of space where the supersystems and sub-systems are identified which is relevant for the search of solution. It will be very clear to the designer of what needed to be changed and what cannot, and at the same time knowing what will the ideal final result looks like. These steps have made clear the problems of the case studies and have suggested the category of the solution for the problems presented. The answer to the problem analysis question 2(b) in Table 1 states that 'weight of the impeller should be reduced' while the answer in Table 4 states that 'add heat insulation' for blower impeller and extruder, respectively.

As the categories of the problems are identified for both cases, which are 'material cost (reduction)' and 'thermoregulation', the search for strategies to the problems became straightforward as there are only one and three problems in the two categories, respectively. The problem within the 'material cost (reduction)' category is 'lightweight structures'. To address the issue of light weighting, 15 strategies are suggested in the pattern-based ontology. The solution can either be selected of several strategies and make a hybrid solution out of it, or test out which of the strategies works the best in the embodiment design stage. In this case, the strategy 'layered composite' is selected. As for thermoregulation, the three problems are 'heat insulation', 'keep cool', and 'keep warm'. In this case study, the problem is 'heat insulation' and only three strategies are suggested. The strategies are 'air pockets', 'countercurrent heat exchanger', and 'high specific heat capacity'. Out of this three strategies inspired by different organisms from nature, the strategy that fits the case the most is high specific heat capacity. Besides heat insulation, another problem of the extruder which is also relevant is 'keeping cool'. As the machine operates for a long time, heat will manage to conduct into the feed section and an efficient cooling system is needed. Looking into the problem of 'keep cool', 10 strategies are suggested while the most relevant strategies are 'cooling ribs' and 'increase exposure'. The conceptualisation of the basic design solution is now made possible with the guidance of the suggested strategies. The search and abstraction stage of biomimicry are made efficient by this ontology as less effort is needed to obtain solutions that are able to solve the problem accurately.
Note that there are three ideality principles in all three spaces in Ideal Windows shown in Table 3 and Table 6. These principles are arranged in accordance to their level of influence in terms of the system's space. This is also where the transfer stage of biomimicry takes place as the strategy is evaluated with technical sustainability principles. With these principles, Ideal Windows is able to not only evaluate whether the concept is sustainable or not, but it also pushes the user to think of how can the concept be more cost-effective, energy-efficient, and be users and environmental-friendly. In the first case study of impeller design, the evaluation for user and environmental-friendly is not applicable because it poses no threat towards the engineer at work nor cause any pollution. Therefore, the principle of 'decrease the area of harmful effects' is not applicable as that is the only principle that evaluates sustainability in terms of social and environment. In this case, the focus is more focused towards the material cost aspect. This is why the answer to the principle 'save material cost by using existing material resources' is stated as polymer-metal sandwich panel. As for the case for extruder insulation, there's a harmful effect that needed to be prevent that is the separation of the insulation and breaking as it falls out of the barrel. To prevent this harmful effect, the two insulator need to be bonded together with the barrel by applying high temperature resistance silicone. Unlike the previous case study, the focus of this case is more towards the energy-efficient aspect in cooling the heat transferred. Therefore, in different cases, Ideal Windows is able to assist designers to evaluate the sustainability of generated ideas from different perspectives.

\subsection{CONCLUSION}

With the case studies conducted with these two different industries, it can be concluded that BioPattern is able to assist its user to produce functioning solutions to solve not just inventive problems, but also existing problems faced by the industry. BioPattern is a straightforward design framework where designers and engineers can use it to obtain inspirations and strategies from nature to solve their engineering problems directly without the need to have any biology background as all the abstraction works were done prior to the construction of pattern-based ontology.

\section{Acknowledgement}

This research was funded by Postgraduate Research Grant (GPPS/U799) and RMC, UTHM. The author would like to appreciate Universiti Tun Hussein Onn Malaysia for providing facilities support. 


\section{References}

[1] Bar-Cohen, Y. 2006. Biomimetics - Using Nature to Inspire Human Innovation. Bioinspiration and Biomimetics. 1(1): 112.

DOI: http://dx.doi.org/10.1088/1748-3182/1/1/P01

[2] Thomas, D. B., D. T. Ksepka and R. E. Fordyce. 2011. Penguin Heat-retention Structures Evolved in a Greenhouse Earth. Biol. Lett. 7(3): 461-464.

DOI: http://dx.doi.org/10.1098/rsbl.2010.0993.

[3] Stevens, E. D., J. W. Kanwisher and F. G. Carey. 2000. Muscle Temperature in Free-swimming Giant Atlantic Bluefin Tuna (Thunnus thynnus L.). J. Therm. Biol. 25(6): 419423.

DOI: http://dx.doi.org/10.1016/S0306-4565(00)00004-8.

[4] Stevens, E. D. and J. Kendall. 1974. Vascular Anatomy of the Counter-current Heat Exchanger of Skipjack Tuna. J. Exp. Biol. 61: 145-153.

[5] Kleineidam, C., R. Ernst and F. Roces. 2001. Wind-induced Ventilation of the Giant Nests of the Leaf-cutting Ant Atta Vollenweideri. Naturwissenschaften. 88(7): 301-305. DOI: http://dx.doi.org/10.1007/s001 140100235.

[6] Ocko, S. A. et al. 2017. Solar-powered Ventilation of African Termite Mounds. J. Exp. Biol. 220(18): 3260-3269. DOI: http://dx.doi.org/10.1242/jeb.160895.

[7] Vogel, S., C. P. Ellington and D. L. Kilgore. 1973. WindInduced Ventilation of the Burrow of the Prairie-Dog, Cynomys Ludovicianus. J. Comp. Physiol. 85: 1-14.

[8] Pugno, N. M. 2007. Velcro ® Nonlinear Mechanics. Appl. Phys. Lett. 90(121918): 1-2. DOI: http://dx.doi.org/10.1063/1.2715478

[9] Elia, E. D., S. Eslava, M. Miranda, T. K. Georgiou and E. Saiz. 2016. Autonomous Self-healing Structural Composites with Bio-Inspired Design. Nat. Publ. Gr. 6(25059): 1-1 1. DOI: http://dx.doi.org/10.1038/srep25059.

[10] Mencattelli, L., J. Tang, Y. Swolfs, L. Gorbatikh and S. T. Pinho. 2019. Bio-inspired Design for Enhanced Damage Tolerance of Self-reinforced Polypropylene/Carbon Fibre Polypropylene Hybrid Composites. Compos. Part A, 121 (2019): 341-352. DOI: http://dx.doi.org/10.1016/j.compositesa.2019.03.028.

[11] Chen, Y. et al. 2018. Bio-Inspired Underwater Super OilRepellent Coatings for Anti-Oil Pollution. Langmuir. 34(21): 1-23. DOI: http://dx.doi.org/10.1021/acs.langmuir.8b01061.

[12] Wu, H., Z. Shi, X. Zhang, A. Mateen, S. Xiao and F. Zhang. 2019. Applied Surface Science Achieving an Acid Resistant Surface on Magnesium Alloy Via Bio-inspired Design. Appl. Surf. Sci. 478(2019): 150-161. DOI: http://dx.doi.org/10.1016/j.apsusc.2019.01.181.

[13] Dave, T. and A. Layton. 2019. Bio-inspired Design for Resilient Water Distribution Networks. Procedia CIRP. 80: 275-280. DOI: http://dx.doi.org/10.1016/j.procir.2019.01.020

[14] Panyam, V., H. Huang, K. Davis and A. Layton. 2019. Bioinspired Design for Robust Power Grid Networks. Appl. Energy. 251 (2019): 1-13. DOI: http://dx.doi.org/10.1016/j.apenergy.2019.113349.

[15] Zhao, Y. et al. 2017. Bio-inspired Reversible Underwater Adhesive. Nat. Commun. 8(2218): 1-8. DOI: http://dx.doi.org/10.1038/s41467-017-02387-2.

[16] Nagel, J. K. S. 2014. A Thesaurus for Bioinspired Engineering Design. Biologically Inspired Design. Springer London Heidelberg New York Dordrecht. 63-94. DOI: http://dx.doi.org/10.1007/978-1-4471-5248-4.

[17] Vincent, J. F. V. 2016. Research and Practice on the Theory of Inventive Problem Solving (TRIZ). 1-1 1. DOI: http://dx.doi.org/10.1007/978-3-319-31782-3.

[18] Hoeller, N. et al. 2007. Patterns from Nature. Proc. SEM Annu. Conf. Expo. Exp. Appl. Mech. 2007. 3: 1481-1491.

[19] Vattam, S., B. Wiltgen, M. Helms, A. Goel and J. Yen. 2010. DANE: Fostering Creativity in and through Biologically Inspired Design. Proc. First Int. Conf. Des. Creat. 8: 115-122.
[20] Helfman, C. Y., Y. Reich and S. Greenberg. 2014. Biomimetics: Structure-function Patterns Approach. J. Mech. Des. 136(11): 1-11.

DOI: http://dx.doi.org/10.1115/1.4028169

[21] Foo, C. T., B. Omar and A. Jalil. 2019. Biomimicry - Core Stages, Design Process, and Gaps. Int. J. Eng. Technol. 8(1.1): 15-25.

[22] Ekmekci, I. and M. Koksal. 2015. Triz Methodology and an Application Example for Product Development. Procedia Soc. Behav. Sci. 195: 2689-2698.

DOI: http://dx.doi.org/10.1016/j.sbspro.2015.06.481.

[23] Altshuller, G. S. 2007. The Innovation Algorithm: TRIZ, Systematic Innovation and Technical creativity. 2nd ed. Technical Innovation Center Inc.

[24] Altshuller, G. S. 2004. And Suddenly the Inventor Appeared: TRIZ, the Theory of Inventive Problem Solving. Technical Innovation Center, Inc.

[25] Srinivasan, V. and A. Chakrabarti. 2009. Sapphire - An Approach to Analysis and Synthesis. Iced'09. 417-428.

[26] Chakrabarti, A., P. Sarkar, B. Leelavathamma and B. S. Nataraju. 2005. A Functional Representation for Aiding Biomimetic and Artificial Inspiration of New Ideas. Artif. Intell. Eng. Des. Anal. Manuf. AIEDAM. 19(2): 113-132. DOI: http://dx.doi.org/10.1017/S0890060405050109.

[27] Alexander, C., S. Ishikawa and M. Silverstein. 1977. A Pattern Language: Towns, Buildings, Construction. London, New York: Oxford University Press. DOI: http://dx.doi.org/10.2307/1574526.

[28] Vincent, J. F. V., O. A. Bogatyreva, N. R. Bogatyrev, A. Bowyer, and A.-K. Pahl. 2006. Biomimetics: Its Practice And Theory. J. R. Soc. Interface. 3(9): 471-482.

DOI: 10.1098/rsif.2006.0127.

[29] Baldussu, A. and G. Cascini. 2015. About Integration Opportunities between TRIZ and Biomimetics for Inventive Design. Procedia Eng. 131: 3-13.

[30] Helfman Cohen Y. and Y. Reich. 2016. Biomimetic Design Method for Innovation and Sustainability. Springer International Publishing Switzerland. DOI: 10.1007/978-3-319-33997-9.

[31] Ashby, M. F. 2005. Materials Selection in Mechanical Design. 3rd ed. Italy: Elsevier.

[32] Mechanicalinventions, "Extrusion," Mechanical Engineering, 2019. [Online]. Available: http://mechanicalinventions.blogspot.com/2016/04/plasti c-extrusion-process-principles.html. [Accessed: 12-Nov2019].

[33] Yao, H. et al. 2010. Protection Mechanisms of the Ironplated Armor of a Deep-sea Hydrothermal Vent Gastropod. Proc. Natl. Acad. Sci. U. S. A. 107(3): 987-992. DOI: http://dx.doi.org/10.1073/pnas.0912988107.

[34] Warén, A. 2010. Tech Snail Shell. [Online]. Available: https://www.cbc.ca/news/technology/snail-s-iron-armoureyed-by-military-1.941044.

[35] Weathers, W. W., R. S. Seymour and R. V. Baudinette. 1993. Energetics of Mound-tending Behaviour in the Mallefowl, Leipoa ocellata (Megapodiidae). Anim. Behav. 45(2): 333341.

DOI: http://dx.doi.org/10.1006/anbe.1993.1038.

[36] https://asknature.org/strategy/nest-kept-warm/

[37] https://asknature.org/strategy/shape-shades-andenhances-heat-radiation/

[38] https://asknature.org/strategy/shape-shades-andenhances-heat-radiation/

[39] Nobel, P. S. 1978. Surface Temperatures of Cacti Influences of Environmental and Morphological Factors. Ecology. 59 (5): 986-995.

[40] Lewis, D. A. and P. S. Nobel. 1977. Thermal Energy Exchange Model and Water Loss of a Barrel Cactus, Ferocactus acanthodes. Plant Physiol. 60: 609-616. DOI: http://dx.doi.org/10.1104/pp.60.4.609. 